\title{
26
}

\section{Trends and Patterns of Police-Related Deaths in Brazil}

\author{
Vania Ceccato, Silas N. Melo, and Tulio Kahn
}

\section{Introduction}

In the United States, police-related deaths have attracted the nation's attention after recent cases such as: Ferguson, Missouri; Staten Island, New York; Cleveland, Ohio; and Los Angeles, California (Dennis 2015; Richardson 2015). Yet, Brazil has one of the most violent police forces in the world (Fórum Brasileiro de Segurança Pública (FBSP) 2016). Brazil's police killed more than 11,000 civilians between 2008 and 2013, averaging six people a day. In comparison with Brazil, it took the United States's police over 30 years to kill the same number of civilians, despite an approximately 50\% higher population in the United States (Oatman 2014). Reasons behind such violence in Brazil are many and may vary across the country (see, e.g., Adorno and Salla 2007; Caldeira 2013; Cano 2010; Human Rights Watch (HRW) 1997, 1999, 2009b; Instituto de Pesquisa Econômica Aplicada (IPEA)/Fórum Brasileiro de Segurança Pública (FBSP) 2016; Skogan 2013). In the Brazilian state of São Paulo alone, it is estimated that police killed an average of 500

V. Ceccato $(\bowtie)$

Department of Urban Planning and Environment, Royal Institute of Technology (KTH), Stockholm, Sweden

S. N. Melo

Department of Geography, University of Campinas, São Paulo, Brazil

T. Kahn

Fundação Espaço Democrático, São Paulo, Brazil 
people a year between 2001 and 2011, despite a reduction in homicide general rates. In the same state, there were more police killings (2176) in the past five years than in all of South Africa (1623), which has a much higher homicide rate than São Paulo.

Brazilian police have also suffered from an environment characterized by rampant violence. Many officers killed were in off-duty hours, indicating a lack of protection after work hours (FBSP 2016). This generalized violence has major impacts on society. On the one hand, when police officers are killed, the public experiences a sense of insecurity as the police are supposed to be the ones protecting them from danger (Gibbs et al. 2014). On the other hand, when police kill, especially on the large scale as in Brazil, it puts individuals' constitutional and civil rights in check, directly affecting people's trust in authorities and hope for a functioning democracy (HRW 2009b). Police killings in Brazil are thought to be the most dramatic expression of the lack of democratization of the institutions responsible for public security (IPEA/ FBSP 2016).

This chapter focuses on civilian deaths at the hands of, and in confrontation with, the police, often (but not necessarily) after, or in combination with, a potential or suspected ongoing crime using an average rate of data from 2013 to 2014. The chapter builds on the most recent literature of policerelated deaths in Brazil and relies on new data to characterize trends and the geography of police-related deaths in Brazil from two complementary sources. The chapter also identifies state-level covariates that help interpret the regional variation of rates of police killings against a set of hypotheses drawing from two branches of criminological theory.

International criminological research has long revealed strong associations between police violence and officers' individual characteristics, biased police practices toward marginalized people, a country's culture of violence, impunity, a lack of democracy of police institutions, as well as police organization, education, and practices (Adorno and Cardia 2000; Caldeira 2013; Cano 2010; Chappell and Wilson 1969; Gibbs et al. 2014; Ross 2015). However, many of these previous studies do not explore regional variations in policerelated deaths and their potential covariates; even if they do, they are often based on North American and European contexts (but see, e.g., Cano 2010; Chappell and Wilson 1969; Bruce and Neild 2005). As such, this chapter attempts to connect long-established issues of police violence in the North American context with similar, ongoing debates in Brazil. We share the idea that is important to provide evidence from other contexts since factors affecting police-related deaths in some places may not be relevant in other areas (Gibbs et al. 2014). 
The structure of this paper is as follows. In the first section, we set the theoretical foundation for the study. Second, we overview Brazil as context for this study, followed by a third section containing a short introduction to methods. Fourth, we discuss trends in police violence, examine its geography, and, finally, assess the relationship between police-related deaths and state-level predictors. Finally, we conclude the chapter by reflecting on our findings and discussing directions for future work.

\section{Theoretical Background: Factors Affecting Police Violence}

This study draws on two branches of criminological theory. First, Durkheim (1897) argued that countries going through profound socioeconomic change, uncertainty, and instability may experience anomic conditions that contribute to increased rates of crime and violence. In recent decades, Brazil context has been characterized by rapid political, economic, demographic, and cultural change, especially after the start of the democratization and neoliberalization. It is argued that violence and its effects can be mitigated by pro-social institutions, what Messner and Rosenfeld (1997) called 'institutional anomie theory'. In this case, a well-functioning criminal justice system could be considered an example that would alleviate the effect of anomie.

Another relevant branch of criminology useful for explaining variations in police violence assumes the existence of local and regional factors that promote crime. High levels of violence may be a sign of severe social disorder (Wilson and Kelling 1982), where violence is a mark of socially disorganized communities and marginalization (Sampson and Wilson 1995) often characterized by poor levels of collective efficacy (Bursik 1999; Kornhauser 1978; Sampson et al. 1997; Shaw and McKay 1942). Cultural differences in values, norms, and beliefs are believed to be fundamental in explaining differences in violence, referred to as 'subcultures of violence' in criminology (Messner 1983; Wolfgang and Ferracuti 1982). Some of these environments provide normative support for violent behavior, increasing the likelihood that hostile impulses lead to aggression and violence. Thus, more police killing would be expected where subcultures of violence are the norm.

Based on these two branches of criminological theory, a number of factors affecting police-related deaths in Brazil are identified. First, there are contextual factors determining the long-term level of violence across the country, for example, the degree of urbanization and poverty. In this chapter, although 
contextual factors are relevant for the geographical distribution of policerelated deaths, it is only possible to test them for a period of 24 months from 2013 to 2014 at the interstate level. The implication is that these geographical patterns may not be stable over time but, rather, depend on long-term contextual influences. Second, there are structural factors at the state level directly affecting the geography of violence. For instance, the ways the police are organized and trained vary at the individual state level and are bound to affect police practices in the streets. Next, we focus our discussion on the mechanisms linking these factors to the geography of police-related deaths in Brazil at the individual state level, as they support the interpretation of the empirical analysis presented below.

\section{Violence Generates Violence}

Police-related deaths are just the tip of violence iceberg in a society that 'accepts' violence as part of daily life. In large cities in Brazil, high-crime areas are characterized by open violence among young males, daily sounds of gunshots, and extensive connections between everyday crime, drug dealing, ready access to illegal weapons, and constant confrontations with the police and military (Ceccato et al. 2007; Melo et al. 2016; Zaluar 2012) which produces a culture of violence where police officers 'shoot first and ask later'. Out of fear, both police officers and criminals preemptively kill as fear and violence feed each other. There is no access to dispute-resolution structures or mediators (such as lawyers or legitimized community representatives). Even if they exist, they might be perceived as corrupt (Ahnen 2007); thus violence may be seen as the only possible means for problem solving. Zaluar (2012) notes that lack of policing, police corruption, and violence led to impunity in Rio de Janeiro and an 'endless war', which placed those who live in poor areas between two opposing armed conflicts: the war between different groups of criminals, and the war between police and bandits, not always focused on repressing crime and enforcing law. In such culture of violence, the importance of shared values is perhaps fundamental to legitimize violence between groups (e.g., between members of opposing gangs, between police and civilians, between militias and bandits), but perhaps also to free them from other more positive societal constraints on violence (e.g., family, or educational or community networks [Ceccato 2014]). For instance, in the United States these shared values and beliefs held by members of (sub)groups, 'subcultures of violence' (Messner and Rosenfeld 1999), are seen as important in explaining differences in homicide rates between the Northern and Southern states. 


\section{Institutions, Police Organization, and Training}

Explanations of police violence have long focused on individuals' decisionmaking at the expense of institutional and situational dynamics, which is not necessarily correct and focus should instead look to everyday police practices (Sekhon 2017; Skogan 2013). Police practices are, as argued here, influenced by the broader criminal justice system that controls police institutions and acts at various geographical levels. Police practices are also influenced by the police organization itself along with police education and training. In each Brazilian state the police are divided into civil and military; however, all police training still follows some codes of discipline that stem from the military. Lino (2004) suggests that police education and training are fundamental to enable police to provide a secure environment for the community. Lino (2004) suggests that for the Brazilian case university participation in police education has been shown to be essential to promote basic awareness of social justice, such as human rights. Skogan (2013: 319) confirms these findings by showing that the use of police force in Brazil was less frequent by 'officers who were satisfied with their careers, scored high on a personal professionalism index, supported the reform program and community policing, which was also being promoted. Women, older officers, and those with more education reported less frequent use of force.' Educational and organizational characteristics of the police are identified as relevant to control police brutality (Armacost 2004; Telep 2011). However, more often, Brazil has in recent decades employed military-trained police in marginalized areas to deal with public security. Hoelscher and Norheim-Martinsen (2014: 957) indicate that these militarized programs are bound to evolve 'newer and potentially more accountable forms of policing by constraining indiscriminate use of force and establishing a positive state presence in marginal urban areas'. Caldeira (2013) suggests that the problems of enforcing police accountability remain a challenge in new democracies with a long history of authoritarianism, such as Brazil. Despite democratic advances, the country still struggles to control police violence, impunity, and corruption.

\section{Impunity and Inefficient Judicial Justice}

The key factor that fuels police violence against criminal suspects is the persistent impunity for those officers who commit abuses against individuals. Impunity results from the general inefficiency of the judicial system, compounded by factors that come into play when the victims are poor and possible 
criminals and the suspects are police (HRW 1997). For example, over the past decade, the Rio Police Ombudsman's Office recorded over 7800 complaints against police officers concerning criminal conduct; yet those complaints generated only 42 criminal charges by state prosecutors with only four convictions (HRW 2009b). The same report suggests that the main cause of this impunity is the absence of evidence, often a result of police cover-ups and investigatory failures. Human Rights Watch (2009b) found a broad consensus among nonpolice criminal justice officials that police officers implicated in extrajudicial executions are rarely brought to justice. Additionally, internal monitoring mechanisms, such as ombudsmen, are inefficient and may lack transparency (Almeida 2014) in a system in which the old authoritarian regime still survives.

\section{Organized Crime, Police Corruption, and Availability of Weapons}

Organized crime in Brazil found fertile soil in the rapid changes in the emergence of neoliberal policies and economic globalization of the 1980-2000s. This development supports Durkheim (1897) who suggested that rapid social change creates (anomic) conditions that negatively impact society, as rapid transformations produce a chronic state of deregulation, and crime appears as society fails to develop new norms. In Brazil, rapid social changes coincide with modifications of traditional national borders, which produced a favorable environment for organized illegal activities such as drug trafficking, weapons smuggling, fiscal and financial fraud, pirating of merchandise and services, and falsification of pharmaceuticals (Naim 2006). High levels of violence were linked to the expansion of youth drug consumption, the increased power of criminal organizations in major Brazilian cities, and the rise in conflicts between these criminal organizations. These macro-social changes promoted the emergence of organized crime among the low-income population in Brazil due to the breakdown of traditional mechanisms of juvenile socialization and of equally traditional local social networks (Zaluar 2012). Studies on juvenile delinquency clearly indicate that organized crime, especially drug trafficking, is not restricted to Rio de Janeiro and São Paulo. Since the circulation of money nourishes drug trafficking, smuggling, and weapons (Adorno 2013), it becomes fuel for more violence not only in large cities but also in smaller municipalities dominated by organized crime, where organized crime and gun violence are interrelated (Gagliardi 2012). Moreover, in urban areas, high percentages of young people living in slum areas perceive the police as corrupt. According to the national victimization survey, $25 \%$ of the inter- 
viewed population in urban areas admitted that they had some form of private security (Zaluar 2012). Security companies offer services in more prosperous areas of the city and are often managed by senior police and military officers (this partially explains the high percentages of police killed off-duty by nonnatural causes), whereas in poor areas 'militias' are run by or linked to lower ranking military policemen, firemen, and prison wardens.

\section{Inequality, Ethnic Bias, and Police Violence}

Sekhon (2017) indicates that in the United States, neither racist nor unconscious biases alone are explanations for police violence; instead Sekhon suggests structural and organizational factors as relevant to explain these shootings. Nevertheless, there has been evidence that the poor and ethnic minorities are more often victims of police violence. Cano (2010) found the existence of racial bias in the use of lethal force by police in Brazil in the states of Rio de Janeiro and São Paulo. His results reveal that black and mixed-race Brazilians overrepresented among victims of lethal police intervention. However, both national and international literature contest these results for several reasons, one being the way racial bias is measured (Grogger and Ridgeway 2006; Sekhon 2017). What is often suggested is that victims of police violence need to be compared with the demographic composition of the population involved with crime instead of with the overall population.

Yet, police-related killings align with layers of vulnerability that go beyond ethnic background. Vargas and Amparo Alves (2010) suggest that there is a correlation between vulnerability to death by the police as they intersect with ethnic background, class, age, and gender. Principles of social disorganization theory and collective efficacy (Kornhauser 1978; Sampson et al. 1997; Shaw and McKay 1942) might be helpful here in linking structural disadvantage, lack of social ties, mistrust in public authorities, and violence. Garmany (2014), using a case study of a Brazilian slum, illustrates how distance between the state and civil society relates to incidents of police violence and ongoing abuse. If social bonds and social control are weak, people resolve conflict through violence.

\section{The Case Study}

We now outline the context of the research, the data analyzed, and our hypotheses. 


\section{Brazil as the Study Area}

Brazil is a democratic federal republic with a presidential system. The country is the fifth largest country in the world (the third largest in the Americas) with 1 federal district and 26 states and a population of 206 million people. The country is one of the most unequal in the world (Gini coefficient of 51.9 compared with 32.4 of the United States in 2012). Although crime is not merely an urban phenomenon, most crimes happen in large urban areas (the state capitals). During the 1980s and 1990s, rapid, unplanned growth of cities was accompanied by soaring crime rates and parallel public dissatisfaction with the inefficiency of the criminal justice system in the decades that followed (Adorno and Cardia 2000; Caldeira 2013; HRW 1997, 1999, 2009b). Brazil has above-average levels of violent crime and particularly high levels of gun violence and homicide. According to the Mortality Information System (SIM) of the Ministry of Health, in 2014 there were 59,627 homicides in Brazil, equivalent to a homicide rate of 29.1 per 100,000 inhabitants. These deaths represent more than $10 \%$ of homicides in the world and put Brazil as the country with the highest absolute number of homicides, and among the 12 countries with the highest homicide rates (IPEA/FBSP 2016). However, there are differences in homicide rates between the Brazilian states (IPEA/ FBSP 2016). For example, while in São Paulo the homicide rate registered in 2013 was 11 deaths per 100,000 inhabitants, in Alagoas, in the Northeast, it was 65 (Exame 2015). It is exactly in Northeast Brazil where the highest increase is found in the last ten years. Although homicide rates have been falling in seven states in the last decade, police-related deaths show signs of increasing, particularly in Sáo Paulo state (Cubas 2012). Between January and September 2014, officers killed 478 people during confrontations, twice as many as during that same period the year before (FBSP 2014). While fewer officers died in the last few years, many more were killed from nonnatural causes on their off-hours. For example, in 2013, 369 off-duty police were killed compared to 191 two years earlier. There are indications that many police officers are killed when off-duty but working as security guards or other related activities (FBSP 2014).

The criminal justice system varies across Brazil as some states have a public affairs office, and others do not; similarly, the availability of an ombudsman's office and how much is spent on public security or invested in police training differ across states (Fig. 26.1). Police in Brazil are organized primarily at the state level despite the fact that the country has both a federal police force and specialized federal police authorities (for highways, railways, and ports of entry) working with preventing interstate and international drug trafficking 


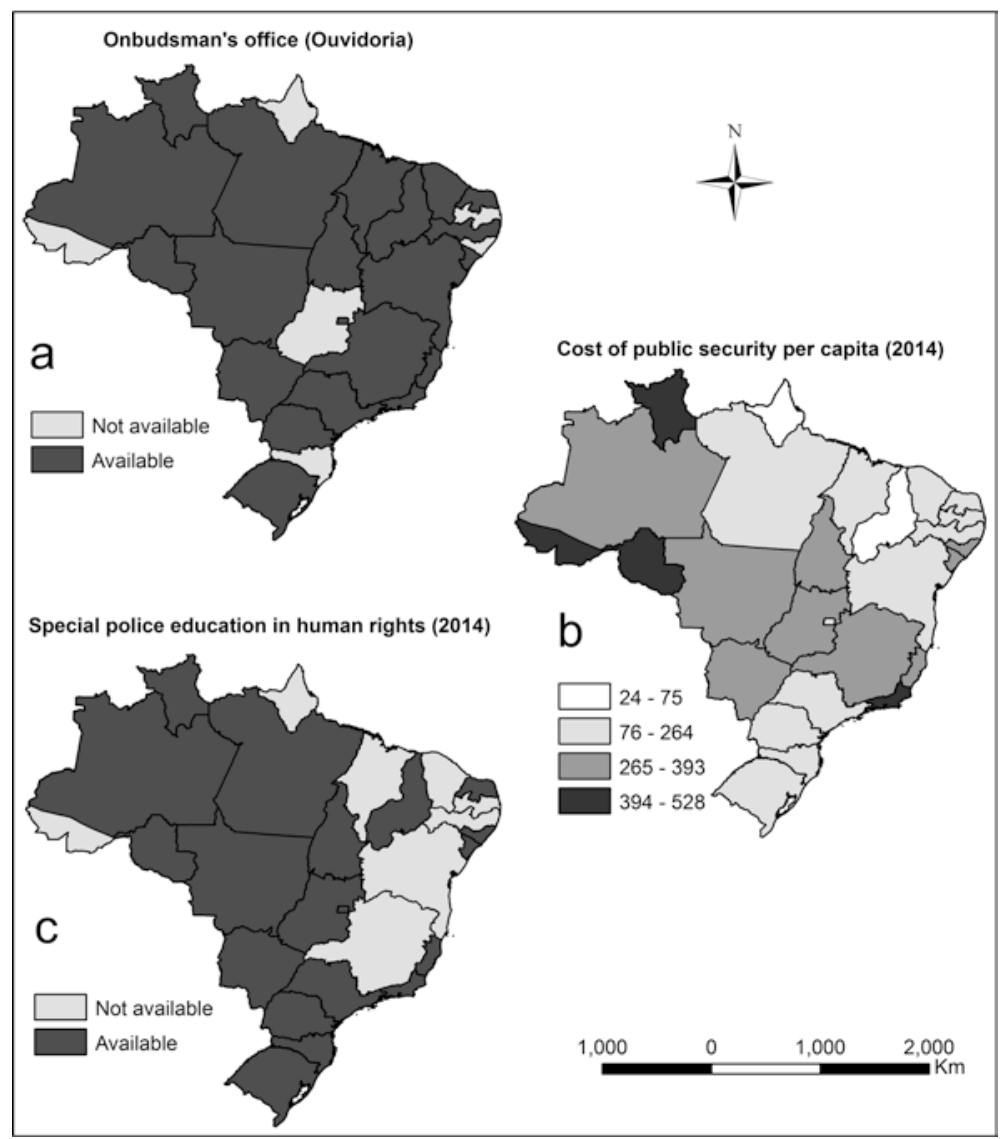

Fig. 26.1 Institutions, investments in public security, and police training in Brazil, 2014: (a) states with Ombudsman's office; (b) costs of public security per capita/state; (c) states with tailored police training in human rights

and smuggling. As in many countries, the state police are divided into two nearly autonomous entities, the civil and military police, which may differ in practice from state to state. Both forces are under the state governor's control, although the military police are also auxiliary and reserve units of the army, and are trained as such.

\section{The Dataset and Data Quality Issues}

The analysis relies on two different data sources, police and health statistics (Table 26.1). The first is collected by FBSP and includes all deaths caused by police intervention, including all individual deaths as a result of confrontation 


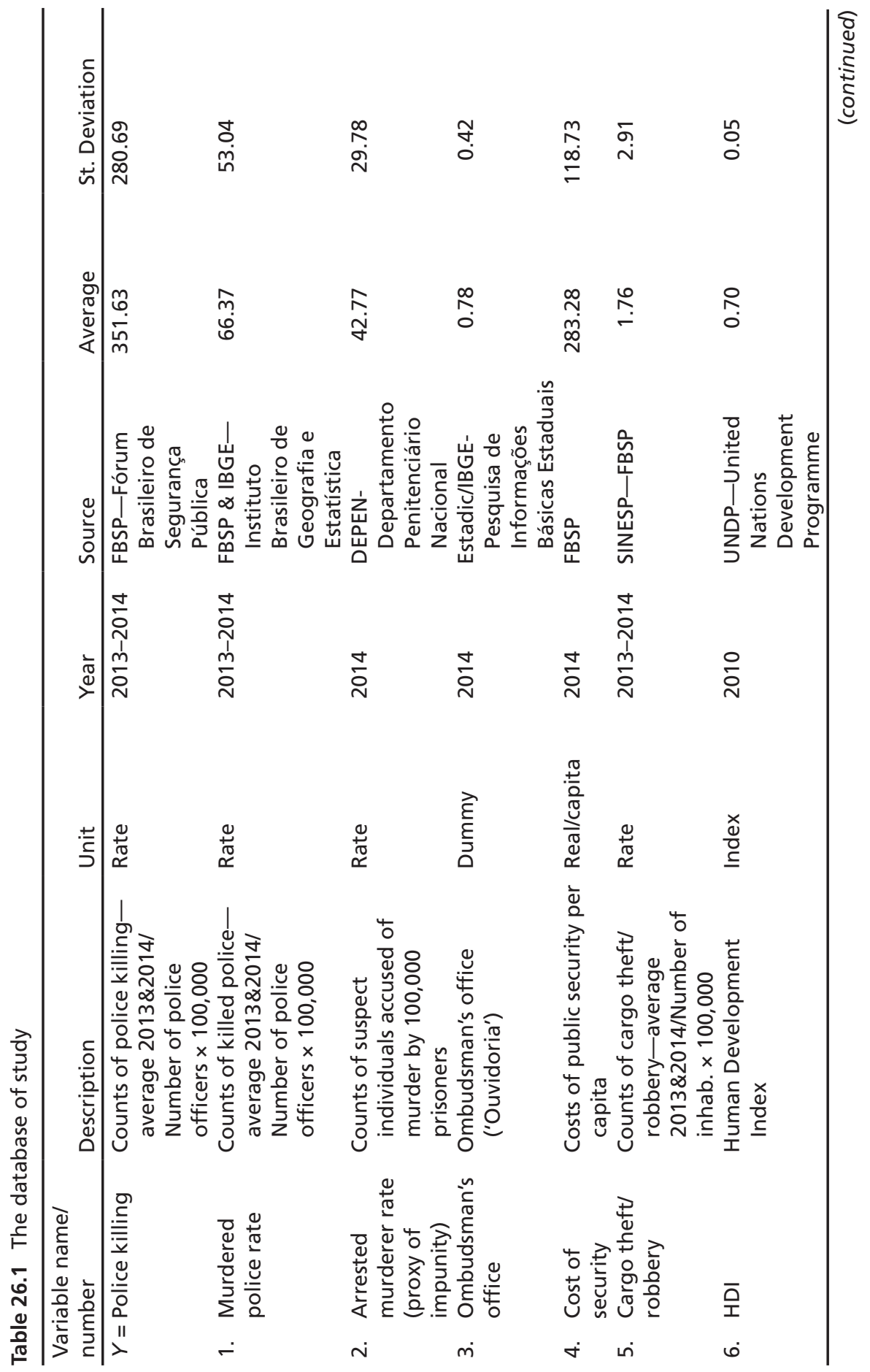




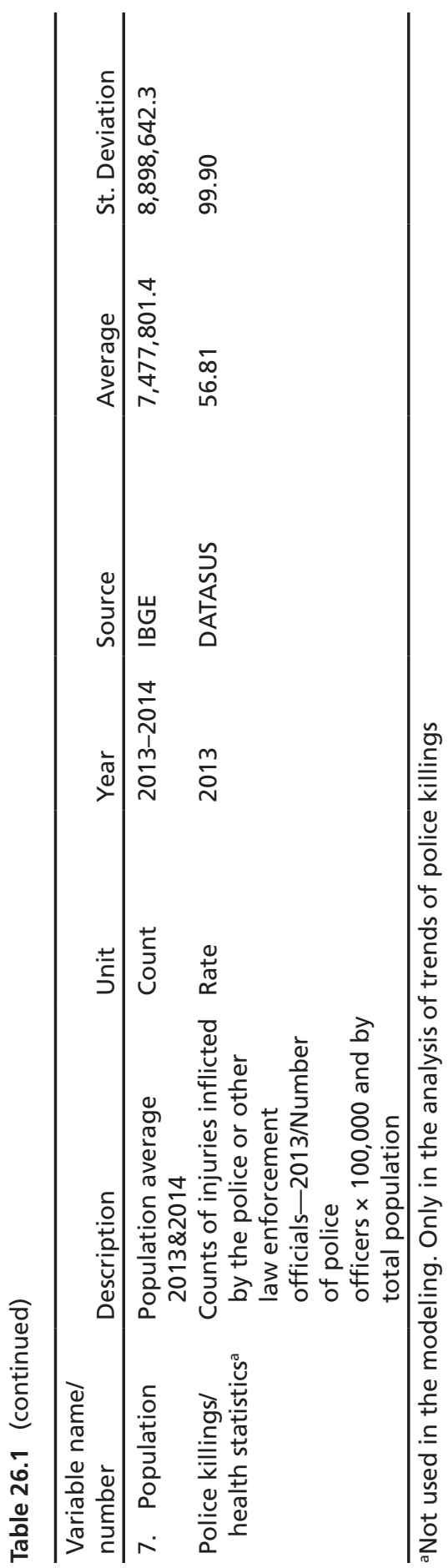


with civil and military police, on- or off-duty (FBSP 2016). The second source is from health statistics (Mortality Information System) and includes all deaths caused by 'legal intervention', namely 'injuries inflicted by the police or other law enforcement officials, including military service during the arrest to maintain order, and other legal action' (World Health Organization [WHO] 2016).

Data on police killings are far from problem-free (Sekhon 2017), especially in Brazil where crime data reporting has a relatively short history (Adorno and Salla 2007) and there is long tradition of systematic recording errors and misrepresentations (Ceccato et al. 2007). Problems of data reliability should not, as Vargas and Amparo Alves (2010: 612) suggest, erase the obvious: 'lethal violence feeds from social environments marked by frequent death'. Yet an unknown portion of these thousands of deaths are due to death squads and militias formed mostly by former officers still active as, for instance, law agents or security guards, and whose numbers of killings are not recorded officially either as perpetrators ('police' killing) or as victims ('police' being killed in confrontation). The states that have a tradition of monitoring (e.g., São Paulo) may show more reliable police killing statistics, while data may be underrepresented in other states. Another challenge is the fact that cases of police killings may be recorded differently by different police and security organizations (e.g., military police, civil police, the Secretariat of Public Security, health statistics). According to IPEA/FBSP (2016), health statistics are the most reliable records of intentional violent deaths in Brazil, but they do not portray reality when discussing lethal police action as recording practices are different. For example, in 2014, only $22 \%$ of cases reported by FBSP were registered by health statistics (681 out of 3009 deaths), and for 2004-2014, only 33\% (6665 out of 20,418 deaths). Therefore, we rely on both data sources as complementary.

It is also important to note that until the late 1990s, there were no official statistics on criminality for the entire country (except health statistics of external causes of deaths). Adorno and Salla (2007) suggest that even after the 1990s, the data available for the years 1999-2001 has to be interpreted with caution. It must also be noted that, over time, there have been changes in crime classification introduced by the Secretary of Internal Affairs of the Military Police. Cases previously recorded as 'resistance followed by death'/'out of service' in 2004 started to be recorded as 'murder'/'out of service', which has contributed to an increase in the number of victims in this classification. Yet, despite these structural problems, the way that the statistics are registered has improved during recent years (for a detailed discussion, see Cubas 2012). 
The population's demographic data were obtained from Brazil statistics (IBGE), while other variables come from a large number of sources: UNDP (United Nations Development Programme) and DATASUS (national basic health statistics). Unfortunately, these statistics are not all available for the same years. The list of dependent and independent variables and the years for which data were available are summarized in Table 26.1 together with their descriptive statistics.

\section{Methods}

\section{Trends of Police Killings}

The analysis concentrates on the period 1992-2014 as this represents the start of relatively accurate data collection following democratization and political stability in the country (for more details, Adorno 2013; Adorno and Cardia 2000). The data is from health statistics, and is known to underestimate police-related deaths, yet is the only database that allows a long temporal analysis.

\section{The Geography of Police Killings}

A local indicator of spatial association was calculated using spatial statistics software GeoDa (Anselin and Rey 2014) to identify states with significantly high concentrations of police killings, taking into account the distribution of police killings in Brazil using FBSP data. Getis-Ord statistics cluster technique was applied to the police killing rates per state. This technique is useful to detect patterns of dependence that may not show up using global measures of spatial association (Getis and Ord 1992). In order to test for location spatial association of police killings, a row-standardized binary weight matrix $(W)$ (queen) was created that comprised nonzero entries where $i$ and $j$ refer to adjacent areas.

\section{Modeling Rates of Police-Related Deaths}

In order to test hypotheses about the statistical significance of different predictors (see below) in explaining the variation in rates of police killings, we first use the information-theoretic approach to analyze empirical data because 
of the potential risk of over-fitting ( 6 variables and 26 states). According to the most recent statistical literature (Burnham and Anderson 2002; McElreath 2015), the information-theoretic approach allows formal inference to be based on more than one model (multimodel inference) and also permits the selection of a 'best' model and a ranking and weighting of the remaining models in a predefined set. Traditional statistical inference can then be based on this selected best model. Selection of a best model represents the inference from the data and tells us what 'effects' (represented by parameters) can be supported by the data. We added total population as a covariate despite the extent to which some of these variables are likely to covary with population size (note that tests were performed without population size with minor variations on the results). Six models (for each variable) were created but we report only the coefficients, the t-values, and the AIC (Akaike information criterion) values of each of them. The final form of the model is:

$$
\log (\text { Police Shooting Rate }) \sim \text { Normal }\left(\begin{array}{l}
\left.\beta_{0}+\beta_{1} \log (\text { Population })\right) \\
+\beta_{2} \log \left(\text { Predictor }_{i}\right), \sigma
\end{array}\right),
$$

for each of the $i \in\{1, \ldots, 6\}$ predictors.

We use Akaike information criterion (its difference and weight) for selection of a parsimonious model as a basis for statistical inference. All models contain the same sample size, otherwise AIC cannot be compared. Then, once all models are fit, the AIC difference and the AIC weight were calculated. For each model ${ }_{i}$ :

$$
\Delta \mathrm{AIC}_{i}=\mathrm{AIC}_{i}-\min (\mathrm{AIC})
$$

and the AIC weight is given by:

$$
\omega \mathrm{AIC}_{i}=\frac{\exp \left(-0.5 \cdots \Delta \mathrm{AIC}_{i}\right)}{S},
$$

where $S$ is the sum of $\exp \left(-0.5 \cdots \Delta \mathrm{AIC}_{i}\right)$ over all models.

The larger is the $\triangle \mathrm{AIC}_{i}$, the less plausible it is than the fitted model, while the bigger is the AIC weight, the better is the performance of the model given the data $x$. A set of variables was excluded from the initial model because they were highly correlated $(r>0.6)$, such as the presence of a public affairs office and an 
ombudsman's office. In the second modeling strategy all the variables were added in the Ordinary Least Square (OLS) model with the intention to confirm the results from the first strategy (modeling the variables individually). Both set of results are presented in section "Predictors of State-Level Police Violence".

For the purpose of this study, we follow the recent strand of research on police violence and hypothesize that current criminological theories may contribute to the explanation of spatial patterns of police deaths. Hence, this study will test the following hypotheses:

Hypothesis 1 Violence generates violence: Rates of police killings are expected to be highest in states with a large proportion of murdered police (Variable 1, Table 26.1).

Hypothesis 2 Impunity and an inefficient judicial system promotes policy brutality: Arrested murderer rate (Variable 2) is used as a measure of impunity; since impunity across the criminal justice system is high, police officers feel the only option is taking justice into their own hands.

Hypothesis 3 Police practices are affected by controlling institutions, police organization, and training. It is expected that rates of police killings are smaller in states with institutions that can positively influence police activities: having an ombudsman's office (Variable 3), investing more than other states in public security (Variable 4).

Hypothesis 4 Organized crime fuels violence: Data on cargo robbery (Variable 5) signifies the impact of organized crime in promoting violence, especially between police and criminals.

Hypothesis 5 Police are more lethal in states characterized by high inequality and marginalization: States with a low development index (Variable 6) tend to be associated with more police violence.

\section{Results}

\section{Trends in Police Violence and Processes of Change in Brazil}

Police killings (in absolute terms and standardized by police contingent and population) show increases since the 1990 s, but particularly in the last 
15 years (Fig. 26.2). Trends of police killings observed in Fig. 26.2 are strongly dependent on a number of specific events that took place in large urban centers (São Paulo and Rio de Janeiro), where police violence concentrates and tends to be well documented, as discussed below.

The Carandiru Penitentiary massacre is indicated by the first peak in 1992, which is considered a major human rights violation in Brazilian history. The killings took place in then Latin America's biggest prison in Sáo Paulo when military police stormed the facility following a prison riot. The massacre left 111 prisoners dead (102 shot by the police and 9 stabbed by other inmates) and none of the 68 police officers were killed. Many of the inmates were shot execution-style or from outside their cells as they hid behind their mattresses for protection. Survivors claimed that the police fired at inmates who had already surrendered or were trying to hide in their cells. It took ten years for the criminal justice system to convict the former police chief of the murder of 102 inmates (BBC 2001). After Carandiru, São Paulo authorities adopted measures that led to the temporary removal of police officers involved in repeated instances of homicide and the creation of an ombudsman's office to hear complaints of police abuse. In contrast, according to a Human Rights Watch report (1997), during that time, authorities in Rio de Janeiro state implemented a series of policies that have produced a dramatic increase in killings committed by the military police, such as the 'bravery promotion' and the 'bravery pay bonus'. Under the terms of these two programs, officers who engage in acts of 'bravery' (often confused with the summary execution of criminal suspects) were eligible for pay raises and promotion. Yet, in 1997 in São Paulo state, the police were once again accused of extreme police brutality in the slum area of Favela Naval in Diadema, and later efforts to prosecute the

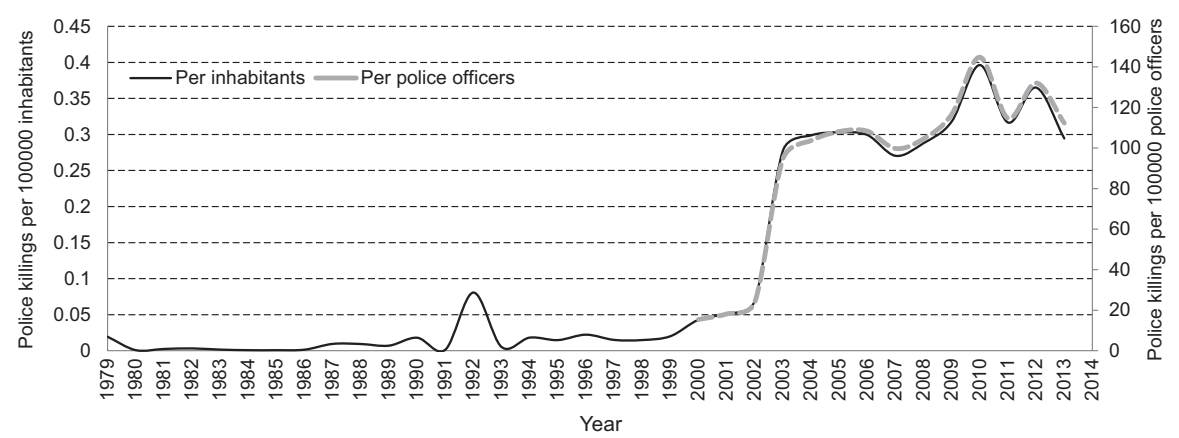

Fig. 26.2 Trends in police killings—rates by total population (1979-2014) and police contingent (2000-2014). Data sources: Basic Health Indicators, DATASUS 
military police officers responsible for police killings incurred setbacks (HRW 1999).

The significant increase in recorded police killings is partially due to the way police report these offenses (an improvement in data collection and registration practices [see Ministério da Saúde 2013] indicates that the percentage of 'deaths with undefined causes' has recently decreased) and in part to a genuine increase in violence, particularly in Southeast Brazil. Two important waves of violence characterize this period. First, a number of simultaneous prison rebellions in 2001 orchestrated by organized crime, particularly the so-called First Command of the Capital (Primeiro Comando da Capital $[\mathrm{PPC}]$ ), which developed from the prisons in Sáo Paulo. The deaths did not happen in prisons but in the home territory of these organizations in São Paulo state, particularly in cities with maximum-security facilities. Second, in 2006, 439 people were killed by gunfire in São Paulo state (an exceptionally high number of deaths over a short period); PPC's drug faction launched a series of assaults against police posts in São Paulo, gunning down 43 police officers (HRW 2009b). These deaths were accompanied by waves of violence including rebellions in 73 prisons in the state, aggression and attacks against public agents (above all police officers and correctional officers), civilians, private buildings (such as banks) and public buildings (such as police stations), as well as arson against public property, especially public transportation. Adorno and Salla (2007) suggest that there have been a number of social, political, and institutional conditions that together supported the emergence of organized criminality inside Brazilian prisons that consequently led to massive waves of violence in the country. Moreover, organized criminality flourished within the prisons due to the massive incarceration policy executed by the state governments in the 1990s and 2000s (see Chap. 36 in this book).

At the same time, generalized impunity has led to corruption. Police in Rio and São Paulo were accused several times of 'planting evidence', such as guns or drugs, on police shooting victims. This is a form of tampering with evidence and, according to HRW (2009b), though not definitive, supports a finding that the killings were unlawful. The practice of planting evidence on otherwise innocent victims of extrajudicial police executions has been proven in trial in at least three cases.

One of the most recent peaks of violence, in 2012, was triggered by conflicts between police and organized crime in the state of São Paulo. Police statistics indicate that about 100 police officers were targets of violence and a total of 41 police were executed. Many of the police officers' deaths have been followed by indiscriminate killings of drug traffickers or theft suspects in what, according to national media, has been characterized as acts of retaliation 
by the military police. It is not surprising that under such circumstances, the experience of filing a police abuse complaint at a police precinct leaves the victims and families of victims feeling frightened and vulnerable to reprisals and retaliation.

\section{The Geography of Police-Related Deaths in Brazil}

Figure 26.3a, b complement each other. First, note that Fig. 26.3a shows rates of policing killings by state from FBSP data, while Fig. 26.3b shows where the statistically significant hot and cold spots of police killings are located across the country using an average rate from 2013 to 2014. Figure 26.3a indicates that the highest rates of police killings are found in Rio de Janeiro, Paraná, Pará, Bahia, and São Paulo, with Rio showing rates four times higher than São Paulo for those two years. This ranking is generally corroborated by health statistics (with Rio at the top followed by Bahia, Santa Catarina, São Paulo, and Pará). All these states, except Bahia and Pará, are located in Southeastern and Southern Brazil, where most of the urban population lives (with two major capitals), where there are high concentrations of wealth but also poverty, strong connections to organized crime, drug dealing, and high rates of overall crime and violence.

Unsurprisingly, São Paulo stands out as a hot spot of police violence (Fig. 26.3b), partially because many of the events described happen there but also because of good reporting practices. The states surrounding São PauloParaná, Rio de Janeiro, Minas Gerais, and Mato Grosso do Sul—also show relatively high rates of police killings. In the case of Sergipe, the cluster is dependent on relatively high rates in the states of Alagoas and Bahia. The hot spots indicate some spread process that are likely to be linked to the criminal structure of regions, often acting beyond borders. Cold spot states-Rondônia (a state surrounded by the Amazon, Acre, and Mato Grosso) and Ceará (which constitutes an area of transition between the Northeastern and Northern regions)_are surrounded by the most remote and low-density populated states of the country.

\section{Predictors of State-Level Police Violence}

We applied two modeling strategies. In the first strategy (modeling the variables individually, see Burnham and Anderson 2002; McElreath 2015), results show that the variables 'Arrested murderer rate' and 'Rate of murdered 


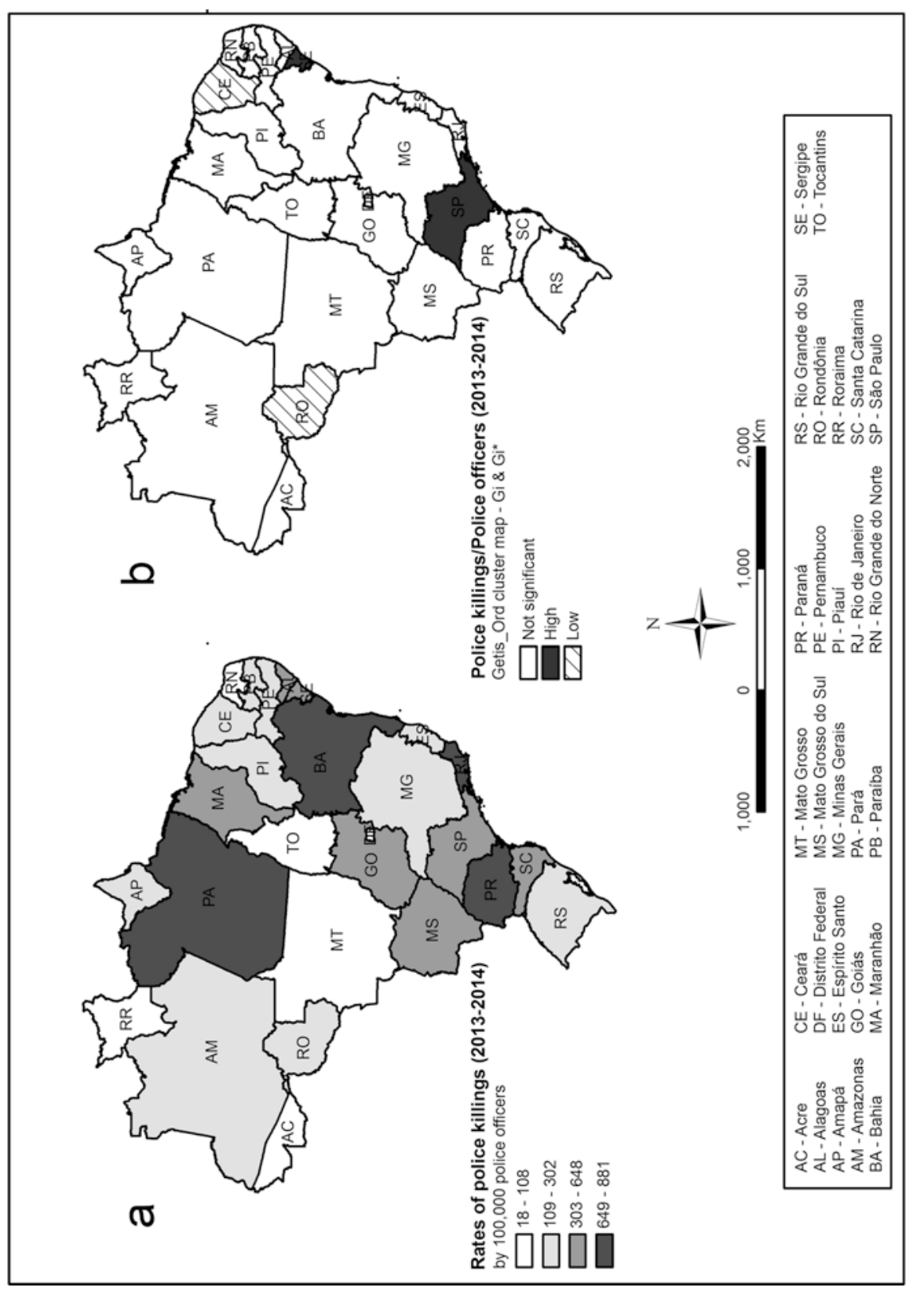

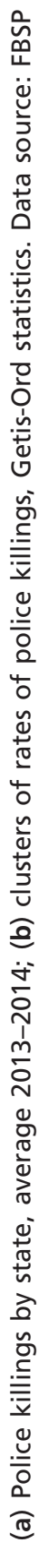

ஸे 훙으 
police officers' (police as victims) perform better than any other variable when modeled individually (the low $\Delta \mathrm{AIC}_{\mathrm{i}}$ level gives strong empirical support of these models; this is also confirmed by model's AIC weight [Table 26.2]). The 'Arrested murderer rate' variable alone explains 35\% of the variation of police killing rates, while the 'Rate of murdered police officers' explains $26 \%$. The explanatory power of the four other variables is much less, around $20 \%$ of the variation of police killing rates. Cargo theft is the third most important model followed by the variable HDI (Human Development Index) and, finally, the variable ombudsman (all expected signs).

In the second modeling strategy, all these variables were added in the Ordinary Least Square (OLS) model. Note that 'Arrested murderer rate' and 'Rate of murdered police officers' are the only variables that turned out significant in all models (Table 26.3). The presence of the ombudsman in the state also has a decreasing effect on police killings, which is indicated in the lag model. Diagnostic checks confirm that the errors are normally distributed (Jarque-Bera test) and heteroskedasticity is not a problem (Breusch-Pagan test). By inspecting the multicollinearity condition, we notice that there is a problem (indicated by a value of 63), despite the fact that shows a weak trace of bivariate correlation (Table 26.4, Appendix). The test for spatial autocorrelation of the residuals (Moran's I) is significant at less than 5\% in the Ordinary Least Square (OLS) model. In this case, a common practice is to fit a spatial autoregressive model to handle the autocorrelation problem. The lagged response model includes a lagged form of the response variable as one of the independent variables, and results are shown in the second set of columns in Table 26.3 together with the Spatial Error model. Results from these three models indicate the importance of two variables (Arrested murderer rate' and 'Rate of murdered police officers') and provide evidence to corroborate hypotheses 1 and 2 that violence generates violence and that violence may be triggered by impunity. In summary, the two tested modeling strategies produced similar set of variables that help 'explain' the spatial variation of police killings in Brazil.

\section{Potential Explanations of State-Level Police Violence}

Police killings are higher where more police officers are murdered but also where there are more signs of impunity. Yet, lethal violent outcomes, either among divergent criminal gangs or between individuals and the police, have to be placed in a context where organized crime might be present and where there is little or no access to dispute-resolution structures. The point is that even if dispute-resolution structures exist, they might be perceived by many as inefficient and/or corrupt; thus revenge and retaliation are regarded as the 


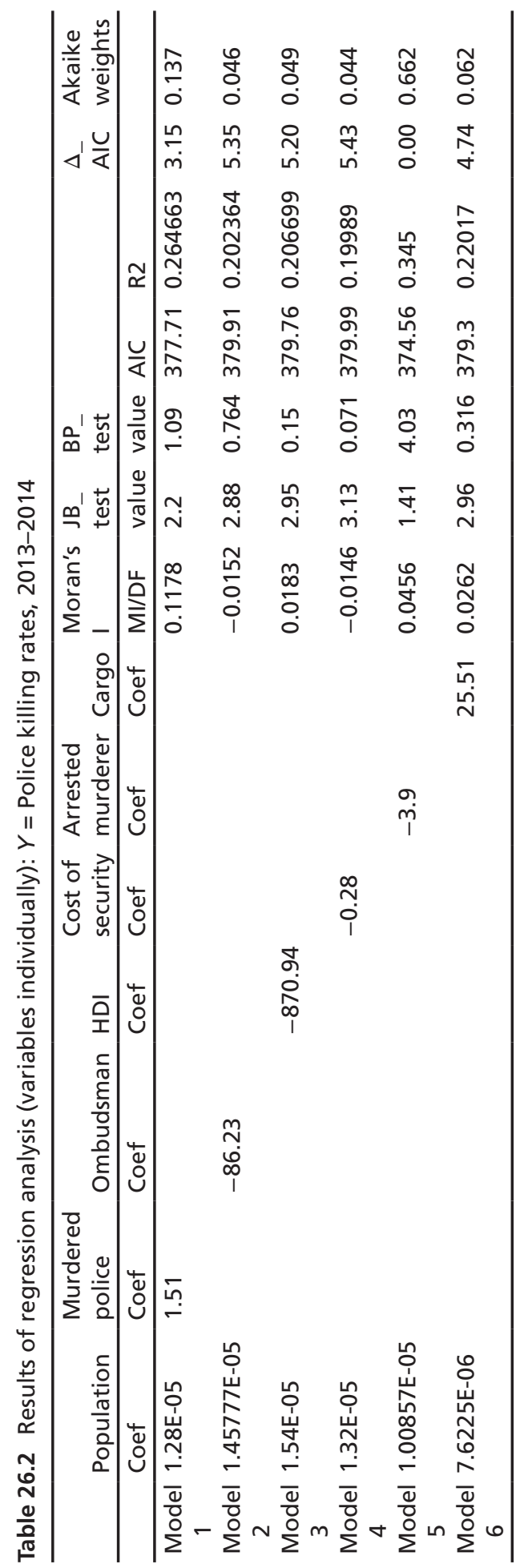


Table 26.3 Results of regression analysis: $Y=$ Police killing rates, 2013-2014

\begin{tabular}{|c|c|c|c|c|c|c|}
\hline & \multicolumn{2}{|c|}{ OLS model } & \multicolumn{2}{|c|}{ Lag model } & \multicolumn{2}{|c|}{ Error model } \\
\hline & Coef & $t$-value & Coef & $z$-value & Coef & $z$-value \\
\hline $\begin{array}{l}\text { Murdered police } \\
\text { rate }\end{array}$ & 1.97 & 2 & 2.36 & 2.99 & 2.54 & 3.33 \\
\hline $\begin{array}{l}\text { Arrested murderer } \\
\text { rate }\end{array}$ & -4.4 & -2.51 & -4.54 & -3.25 & -4.58 & -3.36 \\
\hline $\begin{array}{l}\text { Ombudsman's } \\
\text { office }\end{array}$ & -160.9 & -1.38 & -164.9 & -1.77 & -125.6 & -1.57 \\
\hline Cost of security & -0.31 & -0.77 & -0.21 & -0.64 & -0.31 & -0.87 \\
\hline $\begin{array}{l}\text { Cargo theft/ } \\
\text { robbery }\end{array}$ & 11.58 & 0.44 & 6.69 & 0.31 & 7.66 & 0.34 \\
\hline HDI & 589.67 & 0.49 & 446.27 & 0.46 & 614.9 & 0.47 \\
\hline $\begin{array}{l}\text { Spatial weights } \\
\text { matrix W (police } \\
\text { killings rate) }\end{array}$ & - & - & 0.29 & 1.51 & - & - \\
\hline Lambda & - & - & - & - & 0.49 & 2.58 \\
\hline R-square & 0.51 & & 0.56 & & 0.59 & \\
\hline Adj R-square & 0.33 & & - & & - & \\
\hline $\mathrm{AIC}$ & 376.441 & & 376.275 & & 373.562 & \\
\hline LIK & -180.22 & & -179.13 & & -178.78 & \\
\hline $\begin{array}{l}\text { Unsolved } \\
\text { problems }\end{array}$ & & & Multico & linearity & & \\
\hline Moran's I (error) & 0.19 & $p=0.02$ & & $p=0.14$ & & $p=0.08$ \\
\hline Jarque-Bera & 1.91 & $p=0.38$ & & - & & - \\
\hline Breusch-Pagan & 6.62 & $p=0.46$ & 5.85 & $p=0.55$ & 7.64 & $p=0.36$ \\
\hline
\end{tabular}

Note: In bold are significant variables at $10 \%, 5 \%$ and $1 \%$ levels. $N=26$

only possible means by which to solve a problem. Recurrent waves of violence-such as those experienced in cities of São Paulo and Rio de Janeiroprovide enough evidence of links between organized crimes and police killings at the intrastate level.

Similarly, findings provide evidence that impunity promotes policy brutality. Impunity in this case is an excuse for the police to be tough. The saying 'we catch criminals, the judicial justice frees them' legitimizes many cases of summary execution to avoid future retaliation from criminals. Police brutality is higher where impunity is reinforced due to the 'absence of evidence', often as a result of police cover-ups and investigatory failures (HRW 1997, 2009b). In practice, it would be expected that this should lead to a feeling of mistrust of the public authorities and weaken police legitimacy. However, one of the model's results indicate that having an ombudsman seems to decrease police violence. This evidence is reinforced by principles of institutional anomie, namely, that pro-social institutions (Messner and Rosenfeld 1997) would help prevent police violence. 
It is important to note that the theory of 'subcultures of violence' as initially suggested to explain variations of homicides in the United States seems to have a number of limitations in supporting the interpretation of the geography of police violence in Brazil. The core idea of subculture of violence theory (Messner and Rosenfeld 1999) is that some subcultures of violence provide greater normative support for aggression than others; therefore, some regions (in the North American context) have more violent encounters than others. However, in countries like Brazil, where violence levels are high for all social strata, we argue that police violence has become an accepted fact of daily life across all segments of society. This does not mean that victimization by the police is equally distributed across society, rather that the culture of acceptance of police violence is normalized throughout all social strata. Under chaotic conditions, it is often a challenge for the police to accurately differentiate criminals from noncriminals and, as a result, violence may occur almost at random. Impunity certainly contributes to police violence since the criminal justice system has a myopic perspective: first by favoring officers (HRW 2009b) and, then, by failing to provide enough protection for on- and off-duty police. Thus, if suspects are put back on the streets after imprisonment, police officers fear retaliation, so the violent route is often preferable (killing before being killed). Extreme police violence is not only legitimized and well accepted within the force (police self-defense), it is also 'encouraged' by some segments of society against those who, for instance, 'deserve' to be punished. The normalization of the culture of violence in Brazil is well-illustrated by the results of a recent survey of those living in large cities (Datafolha 2015): half of the population agrees with the common saying that 'good criminals are dead criminals'.

\section{Limitations}

The analysis shares limitations with other ecological analyses of police violence. First, although the quality and reliability of the data have improved since the beginning of the 1990s, very little is documented about how changes have affected the recording of police violence in Brazil. Second, the spatial units (states) are large, heterogeneous, and few, which limits the hypothesis testing. Although police killing rates are calculated for such areas, they reflect a diversity of underlying societal conditions within each area. Organized crime and criminal networks are a reminder that regions are not sealed units and a feature in one region may trigger higher rates of violence in other areas. Linking crime in an area to the characteristics of that area is only problematic for this reason. 
Finally, regression models fit to area data suffer from the effects of the modifiable areal unit problem (MAUP); therefore, parameter estimates and hypothesis tests are dependent on the scale and partitioning of the study area. Data permitting, future research should try to replicate this analysis at the municipal and/or intra-urban level, or to use time series or cross-lagged regression, that is, one could model the year-specific (or better, month-specific) rates of police killed by civilians and civilians killed by police. Equally important would be to split cases of police killings by hour-on- and off-dutybecause there are recent indications that police-related deaths, especially when police officers themselves are victims, are on the rise. This would provide better grounds to understand both individual circumstances of the cases as well as situational ones.

\section{Conclusions and Recommendations}

This paper has identified trends of cases and rates of police killings in Brazil in recent decades. It has also reported associations between rates of police killings and indicators of inequality, violence, impunity, organized crime, and police organization and training. Based on the evidence gathered in this study, we draw the following conclusions:

1. In Brazil, records of police killings both in absolute and relative terms have increased since the 1990s, with major increases after the 2000s. The significant increase reflects a genuine rise in police violence (particularly in Southeastern Brazil) but also reflects, at least partially, an improvement in the way the records are kept either by police or hospitals. Rebellions in prisons, riots, and confrontations with organized crime are just a few of the circumstances in which police violence may happen. Yet, health statistics highly underrepresent all deaths that happen in confrontation with the police, often after or in combination with a potential ongoing crime. Police killings represent just a portion of overall violence that happens in the country. For instance, Brazil has the highest absolute number of homicides in the world, and these deaths represent more than $10 \%$ of homicides worldwide. Brazil's rapid political, socioeconomic, demographic changes have not been followed by changes in the criminal justice system, police organization and training, or democratization of police institutions that would be expected to positively affect police practices. In the contrary, as the country changed, Caldeira (2013: 236) suggests, 'reforms of the police and of the prison system have been slow and mostly unsuccessful' in trying 
to control police violence and corruption and to make the police abide by democratic principles. This failure is indicated by the high number of civilians killed by the Brazilian police, which do not find any precedent at any social stratum, neither in North America nor in other countries of the Global South.

2. Rates of police killings vary across the country and tend to be concentrated in particular states. The highest rates of police killings are found in the Southeast and South, where most of the urban population lives, where there are high concentrations of wealth but also poverty, strong connections to organized crime, and high rates of overall crime and violence. These hot spots indicate some spread processes that are bound to be linked to the criminal structure of regions, often acting beyond borders.

3. Findings from the modeling corroborate the hypothesis that 'violence generates violence'. In other words, rates of police killings are higher where more police officers are killed. Findings also provide evidence that impunity allows and may even promote policy brutality. Although these results lend weight to some of the previous hypotheses, we argue that future studies should explore other potential intervening factors that contribute to police violence in Brazil, not least including the country's history of slavery and inequality, the organization and ethos of the military police, the devaluation of Brazil's 'surplus population' (e.g., people living in slums), and a highly ineffective criminal justice system.

An outstanding question is whether and how states with a profound problem of police violence might manage to break this spiral of violence. Some of these solutions can be tackled in the short term and may involve measures that state and federal authorities should take to maximize the effectiveness of their practices (see HRW 2009a). However, police violence is just the tip of iceberg of other underlying social problems that stem from a highly unequal society. Instead of opting for short-term quick fixes via police organization and training, long-term efforts should include public policies that can guarantee a state that ensures and reinforces respect for civil rights to all citizens, but particularly marginalized citizens. Long-term actions should include measures that tackle the causes of Brazilian's current disbelief in the fairness of the justice system and its ability to function without bias. Moreover, there is a need to reconsider the acceptable limits of the use of force by the police in a democratic society (Adorno and Cardia 2000). Regardless of context, either in the United States or Brazil, we argue that this question requires a debate about models of police and policing that is compatible with desirable democratic rights of individual citizens. 


\section{Appendix}

Table 26.4 Bivariate correlation of independent variables

\begin{tabular}{|c|c|c|c|c|c|c|c|}
\hline & 1 & 2 & 3 & 4 & 5 & 6 & 7 \\
\hline 1. Murdered police rate & 1 & 0.14 & 0.25 & -0.11 & 0.06 & 0.27 & 0.09 \\
\hline $\begin{array}{l}\text { 2. Arrested murderer rate } \\
\text { (proxy impunity) }\end{array}$ & 0.02 & 1 & -0.20 & 0.24 & 0.13 & -0.11 & -0.27 \\
\hline 3. Cargo theft/robbery & 0.25 & -0.20 & 1 & $0.44^{\mathrm{a}}$ & -0.27 & 0.13 & 0.71 \\
\hline 4. HDI & -0.11 & 0.24 & $0.44^{a}$ & 1 & 0.15 & 0.11 & 0.36 \\
\hline 5. Cost of security & 0.06 & 0.13 & -0.27 & 0.15 & 1 & 0.01 & -0.1 \\
\hline 6. Ombudsman's office & 0.27 & -0.11 & 0.13 & 0.11 & 0.01 & 1 & 0.23 \\
\hline 7. Population & 0.09 & -0.27 & 0.71 & 0.36 & -0.1 & 0.23 & 1 \\
\hline
\end{tabular}

${ }^{\mathrm{a}} p<0.05$

\section{References}

Adorno, S. (2013). Democracy in progress in contemporary Brazil: Corruption, organized crime, violence and new paths to the rule of law. International Journal of Criminology and Sociology, 2, 409-425.

Adorno, S., \& Cardia, N. (2000). Police violence, Democratic transition and rule of law in Brazil (1980-1998). Paper presented at the XXII International Congress of Latin American Studies Association, 16-18 March, Miami, FL.

Adorno, S., \& Salla, F. (2007). Organized criminality in prisons and the attacks of the PCC. Estudos Avancados, 21(61), 7-29.

Ahnen, R. E. (2007). The politics of police violence in democratic Brazil. Latin American Politics and Society, 49(1), 141-164.

Almeida, E. M. (2014). A guide to the perpetuation of human rights violations: Police violence and impunity in brazil. Oxford Human Rights Hub. Retrieved June 17, 2016, from http://ohrh.law.ox.ac.uk/a-guide-to-the-perpetuation-of-humanrights-violations-police-violence-and-impunity-in-brazil/

Anselin, L., \& Rey, S. J. (2014). Modern spatial econometrics in practice: A guide to GeoDa, GeoDaSpace and PySAL. GeoDa Press LLC.

Armacost, B. E. (2004). Organizational culture and police misconduct. George Washington Law Review, 72(3), 453-546.

BBC. (2001). Brazil jail massacre: Policeman convicted. BBC. Retrieved March 11, 2016, from http://news.bbc.co.uk/2/hi/americas/1415178.stm

Bruce, D., \& Neild, R. (2005). The Police That We Want. A Handbook for Oversight of Police in South Africa. Johannesburg, South Africa: Centre for Study of Violence and Reconciliation in association with the Open Society Foundation for South Africa and the Open Society Justice Initiative.

Burnham, K. P., \& Anderson, D. R. (2002). Model Selection and Multimodel Inference: A Practical Information-Theoretic Approach (2nd ed.). New York: Springer.

Bursik, R. J. (1999). The informal control of crime through neighborhood networks. Sociological Focus, 32(1), 85-97. 
Caldeira, T. P. R. (2013). The paradox of police violence in democratic Brazil. In W. Garriott (Ed.), Policing and Contemporary Governance: The Anthropology of Police in Practice (pp. 97-124). New York: Palgrave Macmillan.

Cano, I. (2010). Racial bias in police use of lethal force in Brazil. Police Practice and Research, 11(1), 31-43.

Ceccato, V. (2014). The geographic, socioeconomic, and cultural determinants of violence. In P. D. Donnelly \& C. L. Ward (Eds.), Oxford Textbook of Violence Prevention: Epidemiology, Evidence, and Policy (pp. 77-86). Oxford: Oxford University Press.

Ceccato, V., Haining, R., \& Kahn, T. (2007). The geography of homicide in São Paulo, Brazil. Environment and Planning A, 39, 1632-1653.

Chappell, D., \& Wilson, P. R. (1969). The Police and the Public in Australia and New Zealand. St Lucia, QLD: University of Queensland Press.

Cubas, V. O. (2012). Violência policial in São Paulo. In $5^{\circ}$ Relatório Nacional sobre os Direitos Humanos no Brasil 2001-2010, 312. São Paulo: Núcleo de Estudos da Violência da USP.

Datafolha. (2015, October 5). Datafolha: Para 50\%, 'bandido bom é bandido morto'. O Globo. Retrieved March 11, 2017, from http://oglobo.globo.com/brasil/ datafolha-para-50-bandido-bom-bandido-morto-17688287

Dennis, A. (2015). Good cop-bad cop: Police violence and the child's mind. Howard Law Journal, 58(3), 811-824.

Durkheim, E. (1897). Suicide: A Study in Sociology. New York: Free Press.

Exame. (2015, November 11). Os estados com mais homicídios no Brasil.

Fórum Brasileiro de Segurança Pública (FBSP). (2016). Anuário Brasileiro de Segurança Pública. Retrieved August 31, 2017, from http://www.forumseguranca. org.br/atividades/anuario/

Gagliardi, P. (2012). Transnational organized crime and gun violence. A case for firearm forensic intelligence sharing. International Review of Law, Computers \& Technology, 26(1), 83-95.

Garmany, J. (2014). Space for the state? Police, violence, and urban poverty in Brazil. Annals of the Association of American Geographers, 104(6), 1239-1255.

Getis, A., \& Ord, J. K. (1992). The analysis of spatial association by use of distance statistics. Geographical Analysis, 24(3), 189-206. https://doi. org/10.1111/j.1538-4632.1992.tb00261.x.

Gibbs, J. C., Ruiz, J., \& Klapper-Lehman, S. A. (2014). Police officers killed on duty: Replicating and extending a unique look at officer deaths. International Journal of Police Science \& Management, 16(4), 277-287.

Grogger, J., \& Ridgeway, G. (2006). Testing for racial profiling in traffic stops from behind a veil of darkness. Journal of the American Statistical Association, 405(101), 879-887.

Hoelscher, K., \& Norheim-Martinsen, P. M. (2014). Urban violence and the militarisation of security: Brazilian 'peacekeeping' in Rio de Janeiro and Port-au-Prince. Small Wars \& Insurgencies, 25(5-6), 957-975. 
Human Rights Watch (HRW). (1997). Police Brutality in Urban Brazil. New York, USA: Human Rights Watch.

Human Rights Watch (HRW). (1999). Brazil—Human Rights Developments. Retrieve March 14, 2017, from https://www.hrw.org/legacy/wr2k/americas-01. htm

Human Rights Watch (HRW). (2009a, December 8). Brazil: Curb police violence in Rio, São Paulo: Extrajudicial killings undermine public security. News. Retrieved March 14, 2017, from https://www.hrw.org/news/2009/12/08/brazil-curb-policeviolence-rio-sao-paulo

Human Rights Watch (HRW). (2009b). Lethal Force: Police Violence and Public Security in Rio de Janeiro and São Paulo. Retrieved August 31, 2017, from https:// www.hrw.org/report/2009/12/08/lethal-force/police-violence-and-publicsecurity-rio-de-janeiro-and-sao-paulo

Instituto de Pesquisa Econômica Aplicada (IPEA)/Fórum Brasileiro de Segurança Pública (FBSP). (2016). Atlas da Violência 2016. Brasília. Retrieved August 31, 2017, from http://www.ipea.gov.br/portal/images/stories/PDFs/nota_tecnica/160322_nt_17_ atlas_da_violencia_2016_finalizado.pdf

Kornhauser, R. (1978). Social Sources of Delinquency. Chicago: University of Chicago Press.

Lino, P. R. (2004). Police education and training in a global society: A Brazilian overview. Police Practice and Research, 5(2), 125-136. https://doi.org/10.1080/ 156142604200190270.

McElreath, R. (2015). Statistical Rethinking: A Bayesian Course with Examples. Boca Raton: Chapman \& Hall/CRC Press.

Melo, S. N., Andresen, M. A., \& Matias, L. F. (2016). Geography of crime in a Brazilian context: An application of social disorganization theory. Urban Geography, 1-23. https://doi.org/10.1080/02723638.2016.1255920.

Messner, S. F. (1983). Regional and racial effects on the urban homicide rate: The subculture of violence revisited. American Journal of Sociology, 88(5), 997-1007.

Messner, S. F., \& Rosenfeld, R. (1997). Political restraint of the market and levels of criminal homicide: A cross-national application of institutional-anomie theory. Social Forces, 75(4), 1393-1416.

Messner, S. F., \& Rosenfeld, R. (Eds.). (1999). Social Structure and Homicide: Theory and Research. Thousand Oaks, CA: Sage.

Ministério da Saúde. (2013). Sistema de Informaçôes sobre Mortalidade-SIM. Retrieved March 17, 2017, from http://www2.datasus.gov.br/DATASUS/index. php?area $=0205$

Naim, M. (2006). Ilícito: o ataque da pirataria, da lavagem de dinheiro e do tráfico à economia global. Rio de Janeiro: Jorge Zahar.

Oatman, M. (2014, November 12). US police brutality is bad. This giant Western country's is way worse. Mother Jones. Retrieved March 17, 2017, from http://www. motherjones.com/mojo/2014/11/brazil-police-brutality-kill-6-people-a-day 
Richardson, L. S. (2015). Police racial violence: Lessons from social psychology. Fordham Law Review, 83, 2961-2976.

Ross, C. T. (2015). A multi-level Bayesian analysis of racial bias in police shootings at the county-level in the United States, 2011-2014. PLoS ONE, 10(11), e0141854.

Sampson, R. J., Raudenbush, S. W., \& Earls, F. (1997). Neighborhoods and violent crime: A multilevel study of collective efficacy. Science, 277(5328), 918-924. https://doi.org/10.1126/science.277.5328.918.

Sampson, R. J., \& Wilson, W. J. (Eds.). (1995). Toward a Theory of Race, Crime and Urban Inequality. Stanford: Stanford University Press.

Sekhon, N. (2017). Blue on Black: An empirical assessment of police shootings. American Criminal Law Review, 54, 189.

Shaw, C. R., \& McKay, H. D. (1942). Juvenile Delinquency and Urban Areas. Chicago: University of Chicago Press.

Skogan, W. G. (2013). Use of force and police reform in Brazil: A national survey of police officers. Police Practice and Research, 14(4), 319-329.

Telep, C. W. (2011). The impact of higher education on police officer attitudes toward abuse of authority. Journal of Criminal Justice Education, 22(3), 392-419.

Vargas, J. C., \& Amparo Alves, J. (2010). Geographies of death: An intersectional analysis of police lethality and the racialized regimes of citizenship in São Paulo. Ethnic and Racial Studies, 33(4), 611-636.

Wilson, J. Q., \& Kelling, G. L. (1982). Broken windows. Atlantic Monthly, 249, 29-38.

Wolfgang, M. E., \& Ferracuti, F. (1982). Subculture of Violence-Towards an Integrated Theory in Criminology. Thousand Oaks: Sage.

World Health Organization (WHO). (2016). International Statistical Classification of Diseases and Related Health Problems 10th Revision (ICD-10). Retrieved August 31, 2017, from http://www.who.int/classifications/icd/en/

Zaluar, A. (2012). Turf war in Rio de Janeiro: Youth, drug traffic, guns and hypermasculinity. In V. Ceccato (Ed.), The Urban Fabric of Crime and Fear (pp. 217-237). Netherlands: Springer.

Fórum Brasileiro de Segurança Pública (FBSP). (2016). Anuário Brasileiro de Segurança Pública. Retrieved August 31, 2017, from http://www.forumseguranca. org.br/atividades/anuario/

Vania Ceccato is Associate Professor at the Department of Urban Planning and Environment, Royal Institute of Technology (KTH), Stockholm, Sweden. She is also an affiliated scholar to postgraduation programs in Brazil at Unesp and Unicamp, São Paulo. She is the author of Rural Crime and Community Safety (2015) and Moving Safely, Crime and Perceived Safety in Stockholm's Subways Stations (2014), the editor of the book The Urban Fabric of Crime and Fear (2012), and coeditor of Safety and Security in Transit Environments: An Interdisciplinary Approach. She is the founder and 
coordinator of the network Safeplaces or in Swedish, Säkraplatser, funded by the Swedish National Crime Prevention Council (BRÅ).

Silas N. Melo is a researcher at the University of Campinas (Unicamp), São Paulo, Brazil. His interests include geography of crime in Latin America, environmental criminology, and spatial analysis. His research has recently appeared in international journals, such as Security Journal, International Journal of Offender Therapy and Comparative Criminology, The Professional Geographer, Urban Geography, Journal of Interpersonal Violence, and Applied Geography.

Tulio Kahn is currently a researcher at Fundação Espaço Democrático. He was Director of the Planning and Analysis Department at Sao Paulo State Police from 2003 to 2011. He received his PhD in Political Science from the University of Sao Paulo in 1998. He is an active member of the Human Rights Movement in Brazil and integrates the scientific committee of the Sao Paulo State Foundation for the Research Support (FAPESP). He is currently researching connections between criminality and business cycles. 